\title{
MONITORING OF ANTHROPOGENIC LANDSLIDE ACTIVITY WITH COMBINED UAV AND LIDAR-DERIVED DEMS - A CASE STUDY OF THE CZERWONY WĄWÓZ LANDSLIDE (SW POLAND, WESTERN SUDETES)
}

\author{
Aleksander KOWALSKI ${ }^{1)}$ *, Jarosław WAJS ${ }^{2)}$ and Damian KASZA ${ }^{2)}$

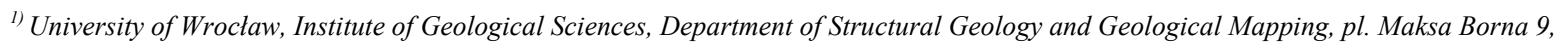 \\ 50-204 Wroctaw, Poland \\ 2) Wrockaw University of Science and Technology, Faculty of Geoengineering, Mining and Geology, 27 Wyb. Wyspianskiego St., \\ 50-370 Wroctaw, Poland \\ *Corresponding author's e-mail: aleksander.kowalski@uwr.edu.pl
}

\section{ARTICLE INFO}

Article history:

Received 20 February 2018

Accepted 13 April 2018

Available online 24 May 2018

Keywords:

Mass movements

Landslides

UAV

LiDAR

Photogrammetry

\begin{abstract}
The paper presents the results of fieldwork and geodetic surveys carried out on a landslide in Wleń (Western Sudetes, Izerskie Foothills). This reactivated landslide occured firstly in 2011 and later on 16th July 2016, following heavy rainfall in the Lower Silesia region, and covered an area of ca. $1100 \mathrm{~m}^{2}$ above the renovated "Leśny Dwór" guesthouse in Wleń town. The main scarp of the landslide is built of strongly deformed Upper Permian (Zechstein) heterolithic deposits, composing the marginal part of the Wleń Graben - a NW-SE elongated, tectonic subunit within the North Sudetic Synclinorium. The landslide was a consequence of undercutting of steep slopes of the Bóbr River valley by anthropogenic activities and loading of the slope surface by blocks and pedestrian paths in the vicinity of the guesthouse.

Monitoring of landslide activity was performed using the initial surface model of the slope subjected to mass movements, LiDAR elevation data, as well as 3D point cloud data from a nonmetric camera on an Unmanned Aerial Vehicle (UAV). They were used to construct digital elevation models (DEMs) of the area covered by the landslide. The DEM from photogrammetric UAV data was processed using Structure from Motion (SfM) technology. The obtained dataset was verified by additional measurement series from terrestrial laser scanning (TLS).
\end{abstract}

\section{INTRODUCTION}

Mass wasting processes, above all landslides, pose critical hazard to human life and infrastructure in urbanized areas. There are numerous cases of landslide-induced construction and natural disasters (e.g. Zhang and Wang, 2007; Ling and Evans, 2014; Wieczorek et al., 2001; Qiu et al., 2017). Therefore, monitoring of landslides and registering of their activity is of crucial importance in urbanized areas. The most commonly used methods of monitoring and observation of landslide activity include geodetic surveys using classical (levelling, tachymetry) and satellite methods (measurements with GNSS technology). Recently, photogrammetric surveys with the application of e.g. UAS, radar interferometry and GIS analysis, are gaining popularity (e.g. Cook, 2017; Assilzadeh et al., 2010; Niethammer et al., 2012; Stumpf et al., 2015; Turner et al., 2015).

Despite the fact that vast and catastrophic landslides are usually associated with high mountains, the percentage of the surface of areas endangered by large-scale mass movements may be equally large in mountainous areas characterized by medium altitudes. A good example are the Flysch Carpathians, where so far almost 58,000 landslides have been inventoried in the Polish part of the area, and their approximate number here may exceed even 100,000 (Wójcik and Wojciechowski, 2016). Intensive landslide activity is also observed in lowlands, mostly on the slopes of river valleys (e.g. Tyszkowski, 2014) and along seacoasts (e.g. Hampton and Griggs, 2004; Violante, 2009; Smith and Mikko, 2017).

Intense geomorphologic and geological studies performed recently in Lower Silesia have revealed the presence of numerous landslide forms in some hill ranges of the Central and Western Sudetes. Knowledge on their morphology and range was enhanced through access and propagation of Light Detection and Ranging (LiDAR) models from the IT System of the Country's Protection against extreme hazards (ISOK). Numerous, so far unknown landslide forms were recognized and described in the last 10 years in the Sudetes, e.g. from the Kamienne (Synowiec, 2003; Migoń et al., 2016), Bardzkie (Sikora et al., 2016b), Bystrzyckie (Gotowała et al., 2015; Różycka et al., 2015), Stołowe (Migoń and Kasprzak, 2011) and Kaczawskie Mountains (Kowalski and Wojewoda 2017), Kaczawskie Foothills (Maciejak et al., 2017), Izerskie Foothills (Kowalski, 2017a) and Zawory Range (Kowalski, 2017b). 
Despite the fact that the landslides in the Sudetes presently occur mainly in forested areas, located far from buildings, some of them have posed serious hazard in the past. A good example is the historical landslide from 1598 in Bardo Śląskie, which caused damming of the Nysa Kłodzka channel and potential flooding of the town (Oberc, 1957). Numerous, smaller landslides occurred also on the embankments of Sudetic rivers during the flood in 1997 (Zieliński, 2001). Despite that, with the exception of the Janowiec landslide in the Bardzkie Mountains in 1997 (Urbański et al., 2015), so far there was no complex and systematic geodetic monitoring of mass wasting in the Sudetes.

This paper presents the evolution of landslide processes in the Bóbr river valley near Wleń (Czerwony Wąwóz) in the Izerskie Foothills (Lower Silesia, Western Sudetes). A model of the initial surface of the slope subjected by mass movement was made. Measurements and analysis of landslide activity included geomorphometric analyses based on LiDAR elevation data and data from an UAV non-metric camera. The methodology of processing photogrammetric models was discussed in numerous reports (Niethammer et al., 2010; Hsiao et al., 2013; Lucieer et al., 2014; Lindner et al., 2016; Rossi et al. 2016; Samieinejad et al., 2017) and similar analyses were performed based on 3D Laser Scanning (Roncella and Florani, 2015) and multi-source DTM's accuracy assessment by volume computation pathway (Wajs, 2015). Based on a series of UAV images, the actual elevation model of the landslide and its morphological forms was prepared, and their verification was made using measurements from terrestrial laser scanning.

\section{STUDY AREA}

Wlen is a small town in the Western Sudetes, located at the junction of three physiographic units the Kaczawskie Mountains and Foothills in the east and the Izerskie Foothills in the west, separated by the Bóbr River gorge valley. Most of the town's buildings occur within a c. $700 \mathrm{~m}$ wide Bóbr meander, where the river changes its course from NE to NW (Fig. 1). The valley embankments reach an elevation of $65 \mathrm{~m}$, and the dip of its slope attains even $78^{\circ}$. The eastern slopes of the valley, at the level of Wlen and Nielestno, have a much gentler inclination at $16^{\circ}$.

\subsection{LOCATION OF THE CZERWONY WAZWÓZ LANDSLIDE}

The studied landslide at present covers a surface of $1290 \mathrm{~m}^{2}$ and is the smallest landslide recognized in the Bóbr valley (cf. Fig. 1; Kowalski, 2016, 2017a). It is located in a valley referred to on tourist maps as Czerwony Wąwóz (Red Gorge). The valley is about $250 \mathrm{~m}$ long; its maximal depth reaches $40 \mathrm{~m}$ and it cuts the north-western slopes of the Bóbr valley to the south of Wlen town. The "Leśny Dwór" guesthouse (German Waldschlösschen) is located at the mouth of the Czerwony Wąwóz valley.
Numerous landslides with a distribution that indicates strong links with the geology of the region occur in the entire Bóbr valley (Sikora et al., 2016a; Kowalski, 2017a). In the stretch where the river flows through the Wlen Graben the largest number of landslides with surface areas from 0.18 to 5.54 ha occurs within Upper Cretaceous sedimentary rocks (cf. Fig. 1 and Kowalski, 2017a). The largest form is the rotational rockslide developed within Upper Cenomanian sandstones on the north-eastern slopes of Świerkowa Dolina Valley to the south-east of Wleń. Smaller landslides occur also further to the southwest, on the slopes of Gniazdo Hill (445 m a.s.1.). They include thin boulder fields in the valley of the unnamed left tributary of Bóbr (e.g. Izerskie Gołoborza) and landslides with a complex origin on the eastern slopes of Gniazdo.

\subsection{GEOLOGICAL SETTING}

The Czerwony Wąwóz gorge incises into the Permian (Rotliegend and Zechstein) and Triassic (Buntsandstein) sedimentary rocks, which together with the overlying Upper Cretaceous deposits form the Wlen tectonic graben (Gorczyca-Skała, 1977) a geological-structural unit bounded by steep NW-SEoriented, normal and strike-slip faults. Sedimentary rocks of the Wlen Graben are cut by basaltoid veins of Neogene age. Their exposures compose volcanic necks occurring in the form of characteristic outliers. The graben basement and its surroundings are built of metamorphic rocks of the Kaczawa complex. They include metabasites, and sericite, chlorite and graphite schists assigned to the Cambrian-Silurian (Milewicz and Frąckiewicz, 1983). The youngest deposits in the study area (excluding alluvial and slope sediments) include Pleistocene sands and gravels of fluvioglacial origin and locally glacial tills reaching $20 \mathrm{~m}$ in thickness (Milewicz and Frąckiewicz, 1983).

\section{RESEARCH METHODOLOGY}

Landslide studies in Czerwony Wąwóz included fieldwork and geodetic surveys, whose results were combined with results of model studies and geomorphometric analyses based on LiDAR data. Fieldwork in the Wleń area was performed in 20152017 during geological and geomorphological mapping surveys. Documentation of landslide phenomena in the Osiedle Południowe (Czerwony Wąwóz) began in February 2016. Mapping in the area included documentation and description of characteristic morphological, lithological and structural elements using GPS receivers such as Nomad Trimble, Juno ST (Trimble) and PENTAGRAM PathFinder Logger P3106, which provide mean accuracy at a level of ca. $2 \mathrm{~m}$. Measurements obtained from these receivers were used to determine the geological boundaries in the study area and the spatial extent of the landslide. Precise measurements of the lengths and widths of forms of the landslide morphology were performed 


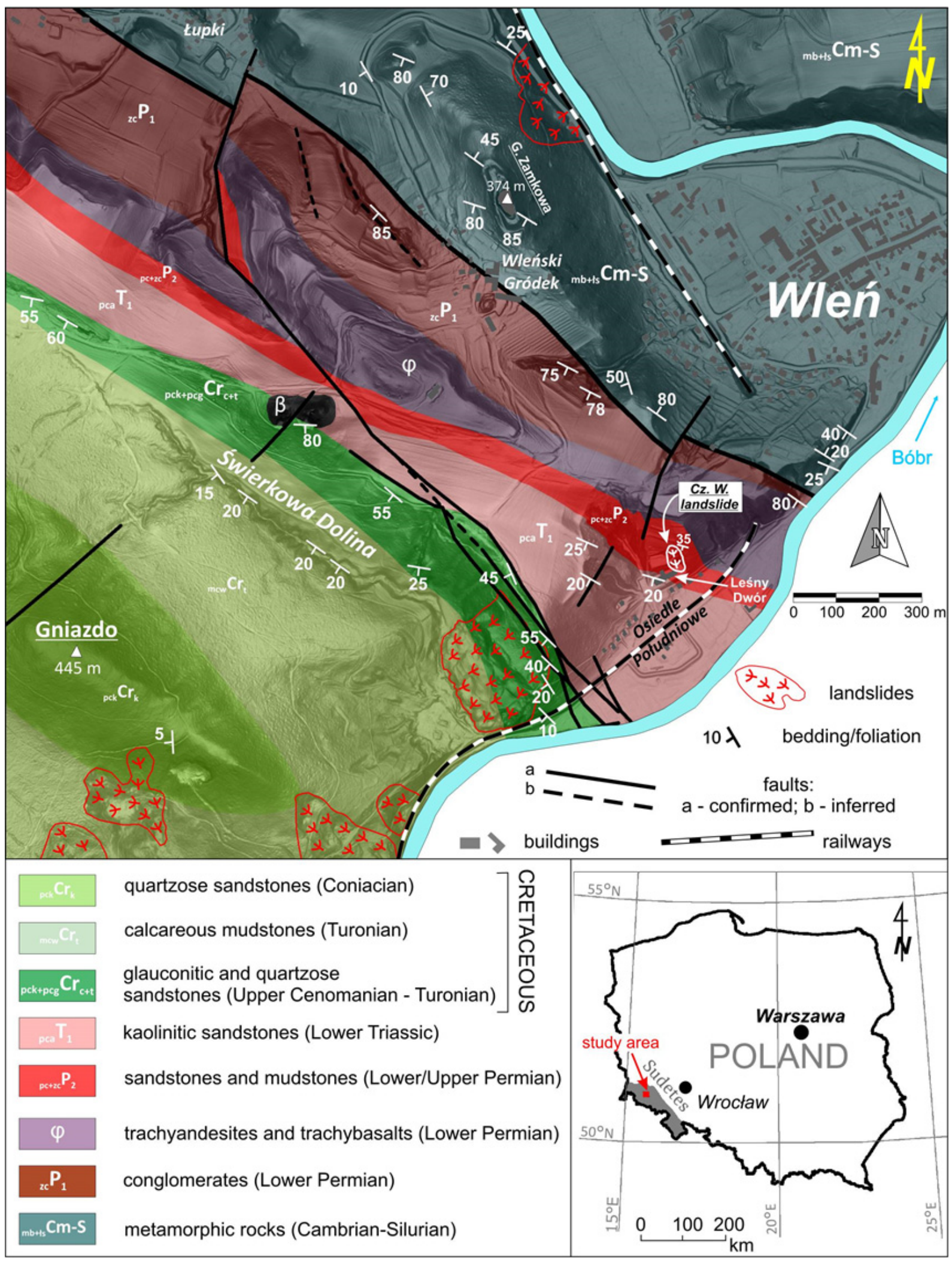

Fig. 1 Detailed geological map of the study area with landslides indicated. Map superimposed on a LiDAR DTM (author: A. Kowalski). 


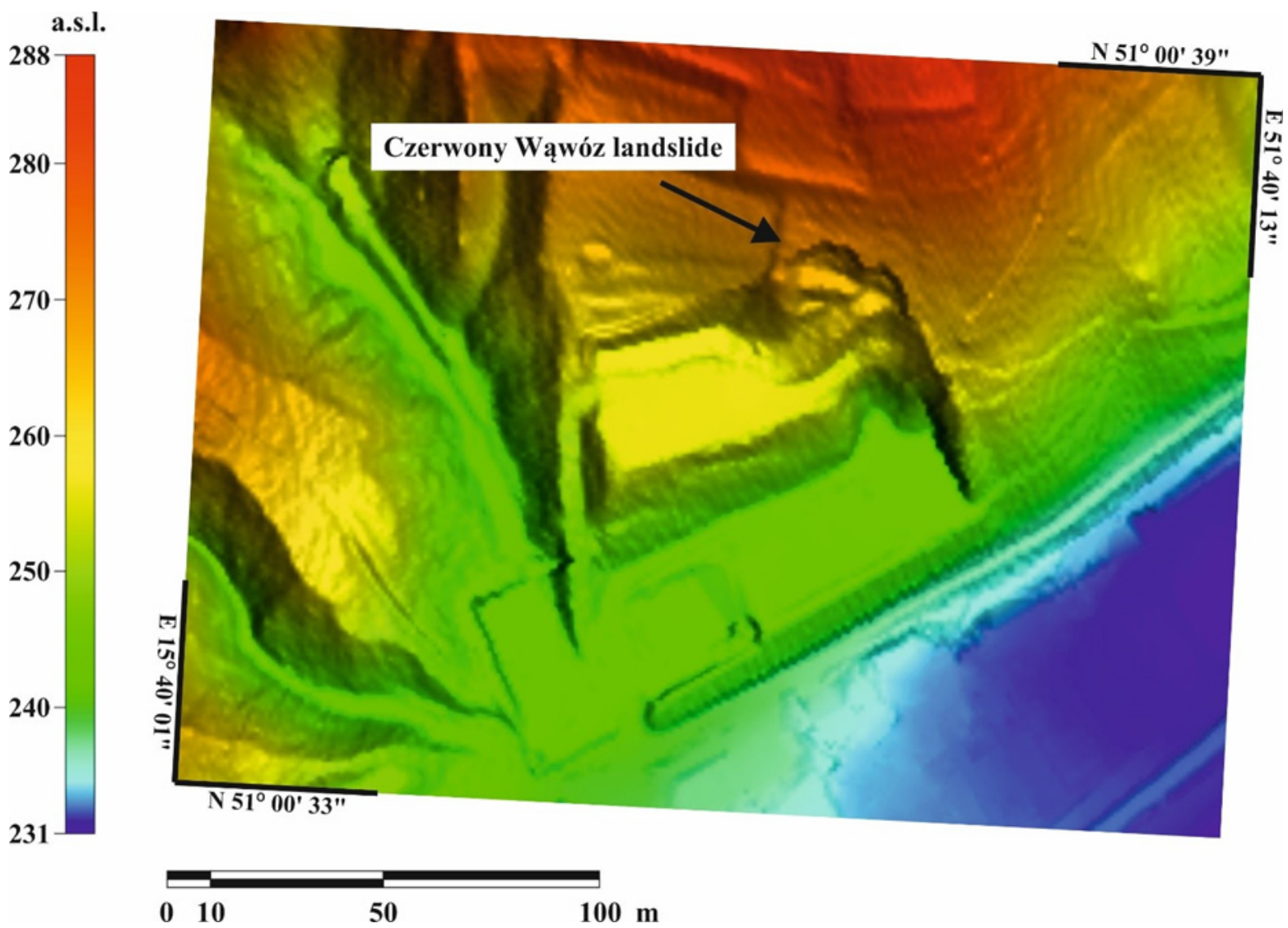

Fig. 2 Shaded relief map of the vicinity of the Czerwony Wąwóz landslide generated from LiDAR DTM.

with a Bushnell laser rangefinder. Field description of landslide activity was made by geomorphologic sketches in .shp format with application of ESRI ArcPad software. Field observations of landscape elements were verified during geomorphometric analyses of LiDAR and UAV digital elevation models. The LiDAR digital elevation model was based on data derived from airborne laser scanning (ALS), performed in Poland in 2011-2014 in the frame of the project of the IT System of the Country's Protection against extreme hazards (ISOK). Flights over the study area were achieved from 21-03-2012 to 30-04-2012 (Fig. 2; CODGiK, 2017). The results of laser scanning in the form of a set of $x y z$ points with the density of about 4-6 measurement points per $1 \mathrm{~m}^{2}$ and an average elevation error not exceeding $0.3 \mathrm{~m}$ (ISOK, 2017) have been made available by the Geodesic and Cartographic Documentation Centre in Poland (CODGiK).

Photogrammetric measurements using the nonmetric camera on a small Unmanned Aerial Vehicle (UAV) were made on 19-09-2017. The UAV platform consists of a hexakopter equipped with a Pixhawk autopilot SLR Sony A6000 (Sony $16 \mathrm{~mm} \mathrm{lens).}$ Ground Control Points (GCP) were distributed beyond the region of the landslide and measured with GNSS RTK precision. Table 1 presents the final compilation of the precision of the SfM report in the process of UAV-derived DTM.

Photographs were processed with Agisoft Photoscan Professional software. The procedure of elaborating elevation data was performed in accordance with photogrammetric constrains presented by Jozkow and Toth (2014) and Rossi et al. (2017). The mean flying altitude AGL (Above Ground Level) was $\sim 35 \mathrm{~m}$ and 40 images were acquired. The final point cloud contains about 4 million points and the post-proceed orthomosaic resolution was $0.02 \mathrm{~m} / \mathrm{pix}$. The final effect of the research as point cloud is presented in Figures 3A, B. The obtained dataset was used as reference point for further analyses including Internal Quality Control (IQC) presented also by Wajs (2016). Additionally, for verification of UAV measurement data, a survey was

Table 1 UAV ground control points RMSE.

\begin{tabular}{ccccccc}
\hline Count & X error & Y error & Z error & $\begin{array}{c}\text { XY error } \\
\text { Total }\end{array}$ & Total & Image (pix) \\
\hline 6 GCP & 3.78 & 2.34 & 1.98 & 4.451 & 4.87 & 1.15 \\
\hline
\end{tabular}




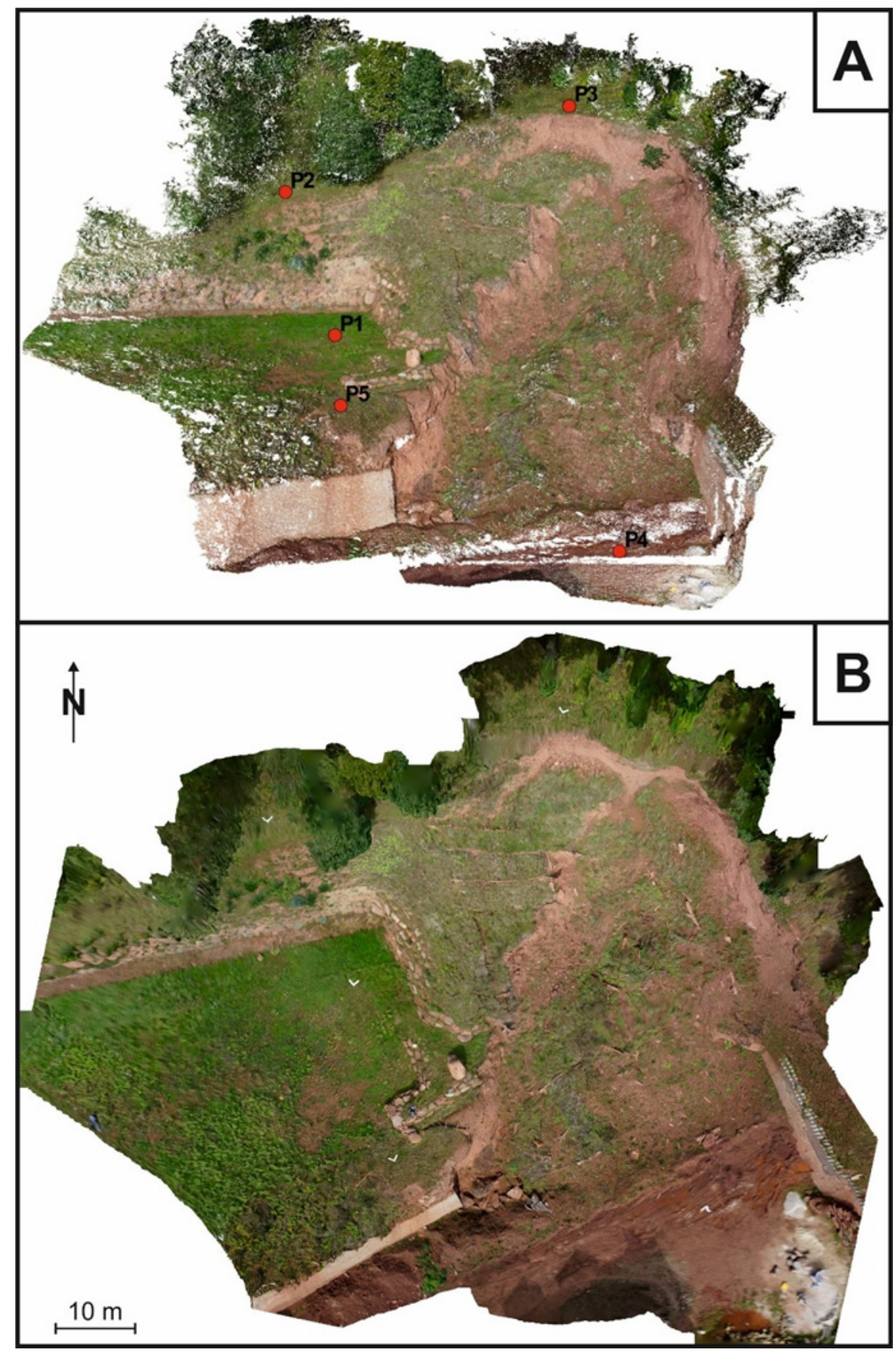

Fig. 3 A) 3D point cloud from UAV with location of Ground Control Points (red circles) from 19-09-2017; B) Orthomosaics of analyzed Region of Interest from 19-09-2017.

performed on 15-12-2017 with application of a terrestrial laser scanner Leica $\mathrm{C} 10$. This operation involved the use of IQC results as absolute distances between the analyzed point clouds - from UAV (as reference) and TLS. The obtained values allowed to identify shifts (movements), which may be potential measurement errors, changes in morphology or terrain coverage.

The point sets obtained from LiDAR and UAV data were used to prepare contour maps and shaded relief maps with various angle and height of the light source. Their further processing was performed using Saga GIS v.3.0.0, MicroDEM, Global Mapper and
Surfer (Golden Software) v. 9.0 software. Maps, geological data and photogrammetric reports were processed in the PUWG 1992 (EPSG 2180) projection.

\section{RESULTS}

\subsection{FIELD OBSERVATIONS, LANDSLIDE MORPHOLOGY}

The first landslide in Czerwony Wąwóz was released after heavy rainfall in 2011 and resulted from damming of part of the slope adjacent to the "Leśny Dwór" guesthouse during construction works in 2009. After the first landslide, at the end of 2011 (Figs. 4 


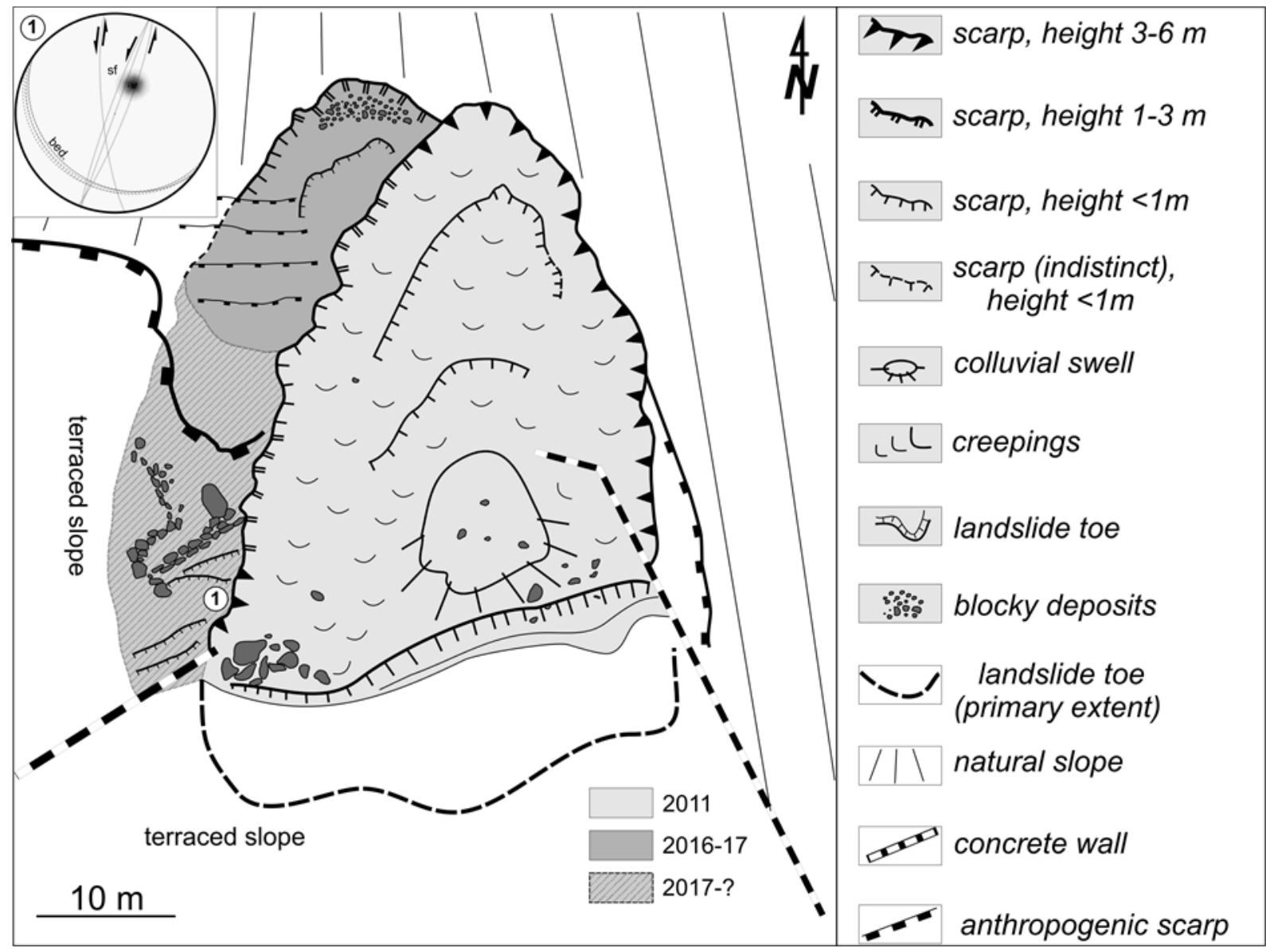

Fig. 4 Geomorphologic sketch-map of the Czerwony Wąwóz landslide with areas affected by mass movements during the time intervals described in the paper. Site of structural measurements is marked (1). The measurements were plotted using a lower hemisphere Schmidt stereographic projection. Explanations: bed. - bedding, sf - strike-slip faults.

and 5A), the landslide niche was terraced and levelled, whereas the adjacent slope was loaded with rock and debris from the zone of the landslide tongue. Rock material was also deposited within the main scarp of the landslide, thus levelling the landslide niche. In 2014 , the base of the slope located at about $20 \mathrm{~m}$ from the guesthouse building was reinforced with an about $6 \mathrm{~m}$ high retaining wall, which was supposed to stabilize the scarp (Fig. 5B).

In March 2016, fractures and fissures appeared on the slope above the guesthouse and the northeastern part of the retaining wall started to crack (Fig. 5C). Above the wall, in the eastern part of the slope, occurred small slides. In May 2016, an about $1.8 \mathrm{~m}$ high arcuate scarp started to develop about $15 \mathrm{~m}$ above the top of the wall (Fig. 5D), whereas on 16-07-2016 intense gravitational movements of rock and debris masses took place, which caused complete destruction of the northern part of the retaining wall along the length of about $25 \mathrm{~m}$ (Fig. 5E). The landslide form that was reactivated at that time had a total surface of about $1100 \mathrm{~m}^{2}$ (Fig. 4). Despite the relatively small area, mass wasting led to serious damage. The retaining wall stabilizing the slope was destroyed and the guesthouse building fell within the range of the landslide tongue. The main scarp of the developed landslide had a length of about $120 \mathrm{~m}$, its height reached from 3 to $7 \mathrm{~m}$, and the dip varied between 50 and $85^{\circ}$ (Kowalski, 2016). In the southwestern part the scarp was rocky and its height reached about $6.5 \mathrm{~m}$. Conglomerates and sandstones with siltstone intercalations were exposed within it. In exposures within the main scarp, numerous normal dip-slip faults and sinistral strike-slip faults were observed (Fig. 4), accompanied by tectonic breccia and strongly plastic tectonic gouge, especially after intense rainfall. Rotated and overturned downthrown blocks cut by secondary scarps, were visible within the landslide colluvium, and a colluvial bulge developed, passing into the landslide tongue zone, which covered the terraced part of the slope at the level of the reconstructed building (Fig. 5F). The landslide tongue was formed from basement rocks and from fragments of the destroyed wall. The landslide toe attained a height from 1 to $3 \mathrm{~m}$.

Directly after the next landslide in 2016, the owners of the guesthouse began to reduce its effects, including levelling of the lowest, terraced part of the slope covered by the landslide tongue (Fig. 5G). As a result of removal of a significant amount of the 

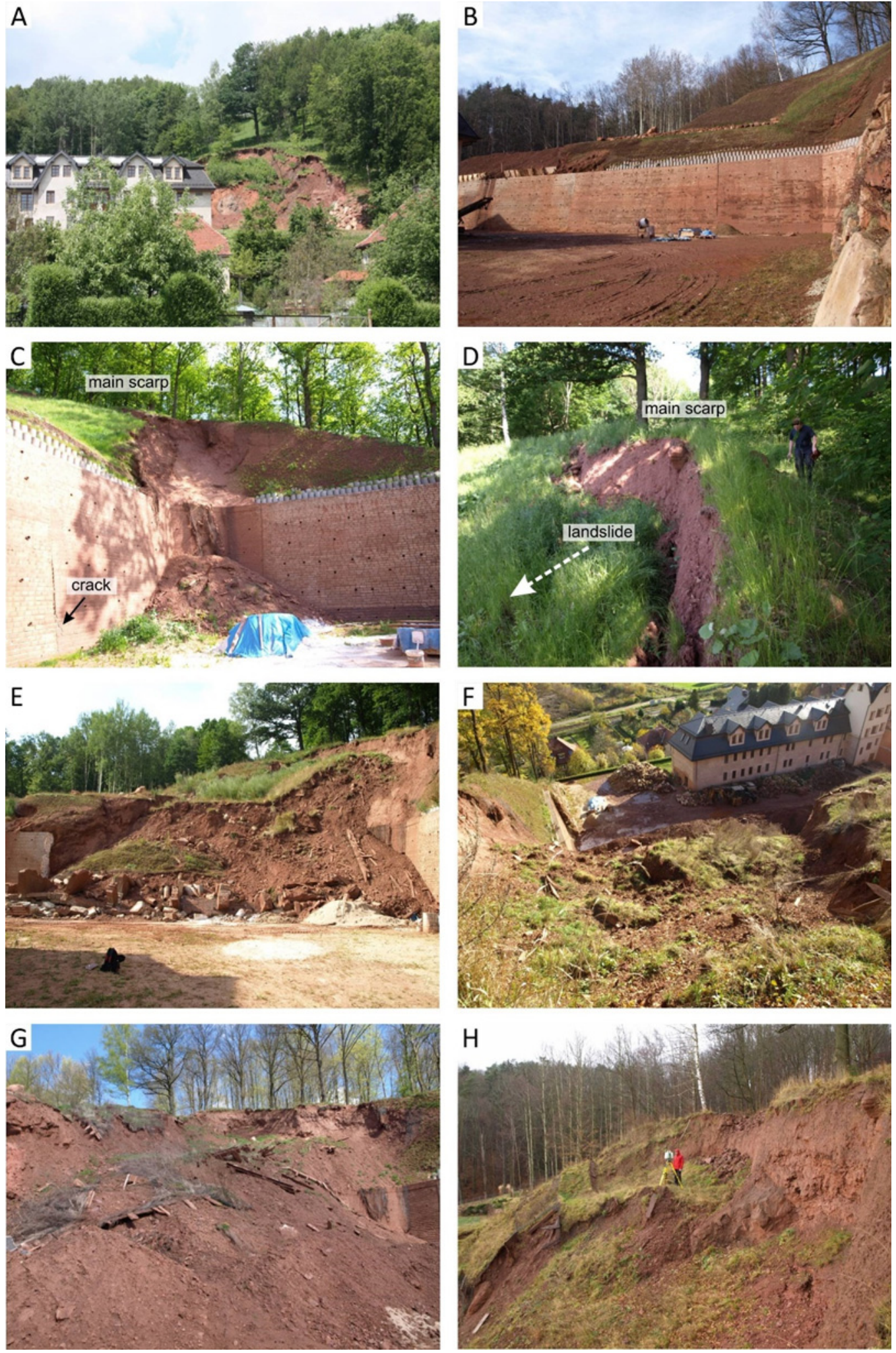

Fig. 5 Czerwony Wąwóz landslide. Initial stage (28-05-2011; photo by K. Maciejak). $\mathrm{B}$ - Retaining wall and terraced slope in the landslide area (5-03-2016). C - small slides on the slope and cracks within the retaining wall (21-05-2016). D - arcuate scarp with a height of $1.8 \mathrm{~m}$ in the upper part of the terraced slope (5-06-2016). E - Landslide formed in July 2016. Fragments of destroyed retaining wall and rock blocks visible within the landslide toe (23-07-2016). F - Landslide niche (30-10-2016). G - Levelled toe of the landslide from 2016 (30-04-2017). H -arcuate secondary scarp developed to the west of the main scarp of the landslide (15-12-2017). 

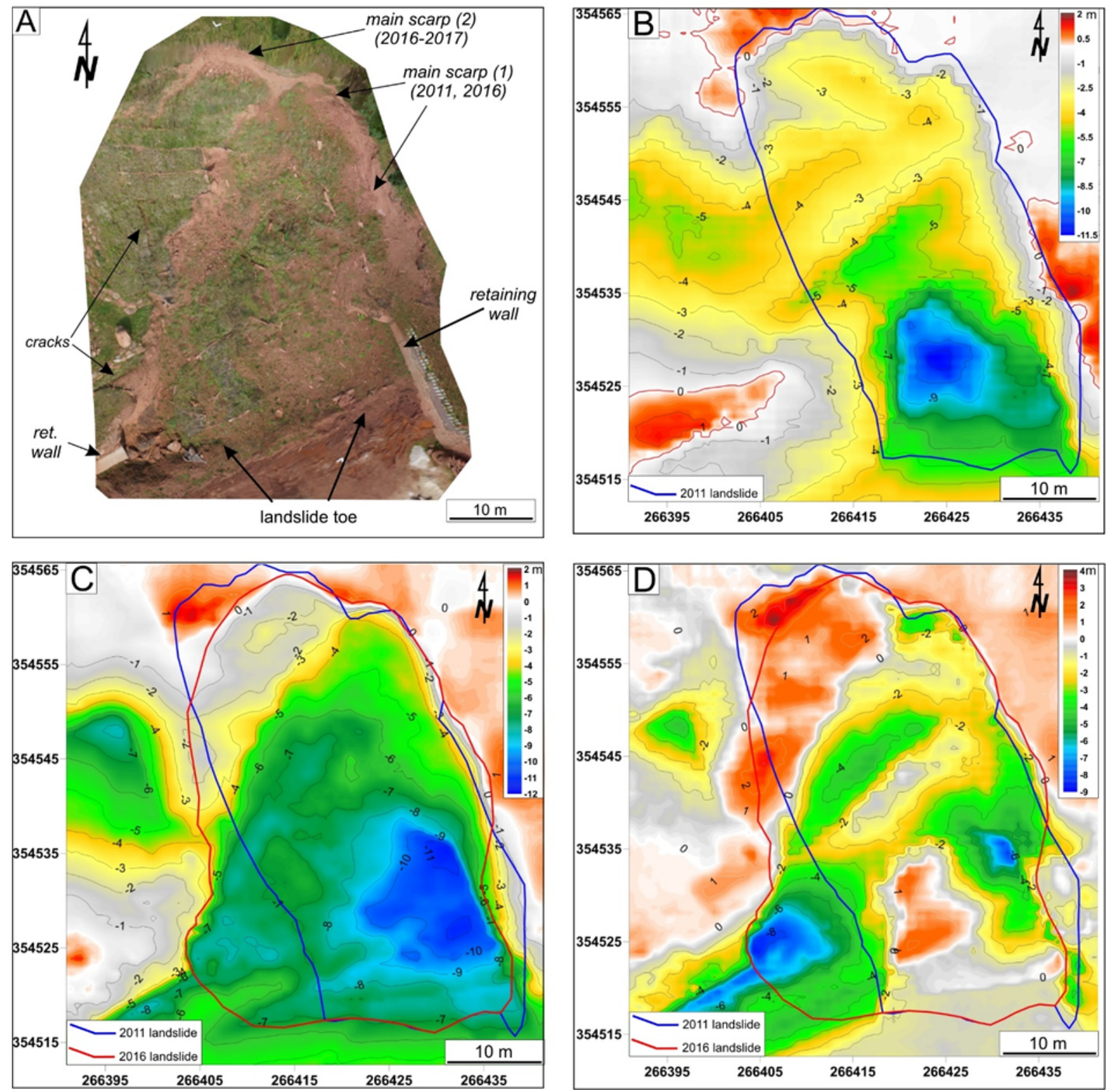

Fig. 6A Czerwony Wąwóz landslide. Orthophoto of the area affected by the landslide acquired from UAV (1909-2017). B - Differential map 1 obtained by subtraction of reconstructed slope surface (before 2009) and LiDAR-derived point clouds (2012). Extension of the 2011 landslide is marked. C - Differential map 2 obtained by subtraction of reconstructed slope surface (before 2009) and UAV-derived point clouds (2017). Extensions of the 2011 and 2016 landslides are marked. D - Differential map 3 obtained by subtraction of LiDAR (2012) and UAV-derived point clouds (2017). Extensions of the 2011 and 2016 landslides are marked. All presented maps show relative height differences within the landslide and its vicinity during the time intervals described in the paper.

colluvium, in the beginning of 2017, to the west of the main scarp, a subsequent landslide developed within the slope debris cover, reaching a length of about $30 \mathrm{~m}$ and height of about 2-3 m. A subsequent landslide packet developed below the scarp (Fig. $5 \mathrm{H}$ ). Smaller scarps and extensional fractures covering the part of the slope loaded by rock blocks by the guesthouse owners developed on the scarp extension.

In the second half of 2017, monitoring of the activity of mass movements was commenced using contact-free, close range photogrammetry from UAV and TLS surveys in order to register and detect the changes (Fig. 6A).

\subsection{LANDSLIDE ACTIVITY IN GEOMORPHOMETRIC ANALYSES}

Differential maps, based on the model of reconstructed slope surface and available reference data (LiDAR, UAV) clearly show zones of relative mass decrement and increment in the area subjected to landslide movements.

Differential map 1 (Fig. 6B) was constructed based on the initial slope model (before 2009) and LiDAR data from 2012. It shows changes that took place in the investigated part of the slope after: terracing by the guesthouse owners in 2009, landslide in 2011 and partial levelling of the landslide niche in 2011/2012. A significant (-3.9 to $-4.2 \mathrm{~m}$ deep), NWSE-oriented depression occurs in the upper part of the 
Table 2 Results of volume computation (mass balance of the landslide area) obtained from LiDAR-, UAV- and TLS-data.

\begin{tabular}{lc}
\hline Landslide & Total volume loss $\left[\mathbf{m}^{\mathbf{3}}\right]$ \\
\hline 2011 landslide & 4840 \\
2016 landslide (UAV) & 7802 \\
2016 landslide (TLS) & 7811 \\
2016 landslide - 2011 landslide (UAV-LiDAR) & 2997 \\
2016 landslide - 2011 landslide (TLS-LiDAR) & 3005 \\
TLS-UAV & 7.5 \\
\hline
\end{tabular}

2011 landslide slope surface. Depressions with similar characteristics occur in the central part of the slope and attain a NE-SW orientation. The relative value of these depressions increases towards the toe of the landslide, reaching $-6.4 \mathrm{~m}$ in its central part. The highest value (c. $-11.2 \mathrm{~m})$ occurs in an oval depression within the lowest part of the landslide. In the frontal part of the landslide form (landslide tongue), the relative depth of this depression reaches about $4.5-6 \mathrm{~m}$. In the slope fragment not subject to mass movements in 2011, positive values $(+1$ to $+1.2 \mathrm{~m}$ ) were noted, decreasing to $-5.3 \mathrm{~m}$ towards the north (terraced part of the slope). Mass increment on the slope surface occurs also on the slope located to the north of the landslide crown (to $+1.2 \mathrm{~m}$ ) and locally on the adjacent, eastern part of the slope.

Differential map 2 (Fig. 6C) was constructed based on the initial slope model (before 2009) and UAV data from 2017. It shows changes on the slope after: levelling of the 2011 landslide, reactivation of mass movements in 2016, and their further development till the end of 2017. The 2016 landslide is larger and, beside the part of the slope covered by mass movements in 2011, it covers the adjacent SW part of the slope. Two distinct, semi-circular depressions with maximal displacement values of $\mathrm{c}$. 2.6 and $-4.8 \mathrm{~m}$ can be observed in the upper part of the 2016 landslide. Depressions in the central part of the slope have values up to $-7.5 \mathrm{~m}$, are semi-circular or correspond with their boundaries to the margin of the landslide. The highest value of vertical displacement (about $-11.5 \mathrm{~m}$ ) occurs in the depression adjacent to the undistorted fragment of the retaining wall in the eastern part of the landslide. In the frontal part of the landslide (landslide tongue), the relative value of the depression reached about $-7 \mathrm{~m}$. Positive values are observed $(+1.3 \mathrm{~m})$ in the fragment of the slope not subjected to landslide movements in 2016; they decrease to $-8.2 \mathrm{~m}$ further to the north (terraced part of the slope). Mass increment on the slope surface took place also on the slope located to the north of the landslide crown (to $+1.6 \mathrm{~m}$ ), as well as locally on the adjacent, eastern part of the slope (to $+1.4 \mathrm{~m}$ ).

The resultant differential map 3 (Fig. 6D) shows the difference between elevation LiDAR and UAV datasets, processed to a vertical resolution of $0.5 \mathrm{~m}$. The map presents relative changes of slope relief between the LiDAR flights (2012) and the UAV measurements (2017). Relative displacement values in the upper part of the reactivated 2016 landslide reach $3.6 \mathrm{~m}$. In its central part occur depressions that reach $4.5 \mathrm{~m}$. Local elevations accompany the depressions (ca. -0.1 to $+0.1 \mathrm{~m}$ ). In the lower part of the colluvium, within the colluvial bulge, the differential map shows zones of positive values with two distinct maxima (1.5 and $2 \mathrm{~m}$ ), with which from the east and west co-occur areas with the smallest depression values within the landslide $(-8.5 \mathrm{~m}$ in the $\mathrm{W}$ and $-7.8 \mathrm{~m}$ in the E). The terraced fragment of the slope adjacent to the landslide area from the west, as well as the slope above the landslide crown are characterized by positive values, to $+3.6 \mathrm{~m}$.

The results of the volume computations (mass balance of the landslide; cf. Chen et al., 2014) based on reconstructed slope surface from LiDAR-, UAVand TLS-derived point clouds, showed that the total deficit of the mass in the 2011 landslide area reached $4840 \mathrm{~m}^{3}$ and ca. $7800 \mathrm{~m}^{3}$ in the 2016 (Table 2). The mass loss in the slope between 2012 (LiDAR data) and the end of 2017 (UAV and TLS data) reached the value of ca. $3000 \mathrm{~m}^{3}$. Difference between TLS and UAV DEMs calculated volume $\left(\sim 7.5 \mathrm{~m}^{3}\right)$ does not exceed $0.1 \%$ of the total 2016 landslide volume.

\section{DISCUSSION}

The evolution of changes within the slope affected by mass movements and anthropogenic changes was recognized based on geomorphometric analyses and systematic field investigations. The values of vertical displacement within the landslide could be assessed. The obtained elevation and model data have allowed for partial imaging of the landslide processes; LiDAR data from 2012 show the stage after landslide occurence but also after its partial levelling by the guesthouse owners. The LiDAR model and the differential maps using this model (Fig. 6B) do not fully reveal the landslide relief but show the overprinting of natural processes (mass movements) and anthropogenic factors (terracing and slope loading). Only the upper part of the 2011 landslide shows a 'natural relief' on differential maps. The central and lower part of the landslide niche was levelled and terraced in 2012, which is reflected in the characteristic, step-like, NE-SW-oriented elevations and depressions (Fig. 6B). The landslide toe area was also regularly levelled, as reflected in the differential maps (Figs. 6B, C) by the lack of two characteristic zones of mass increment and decrement in the upper 


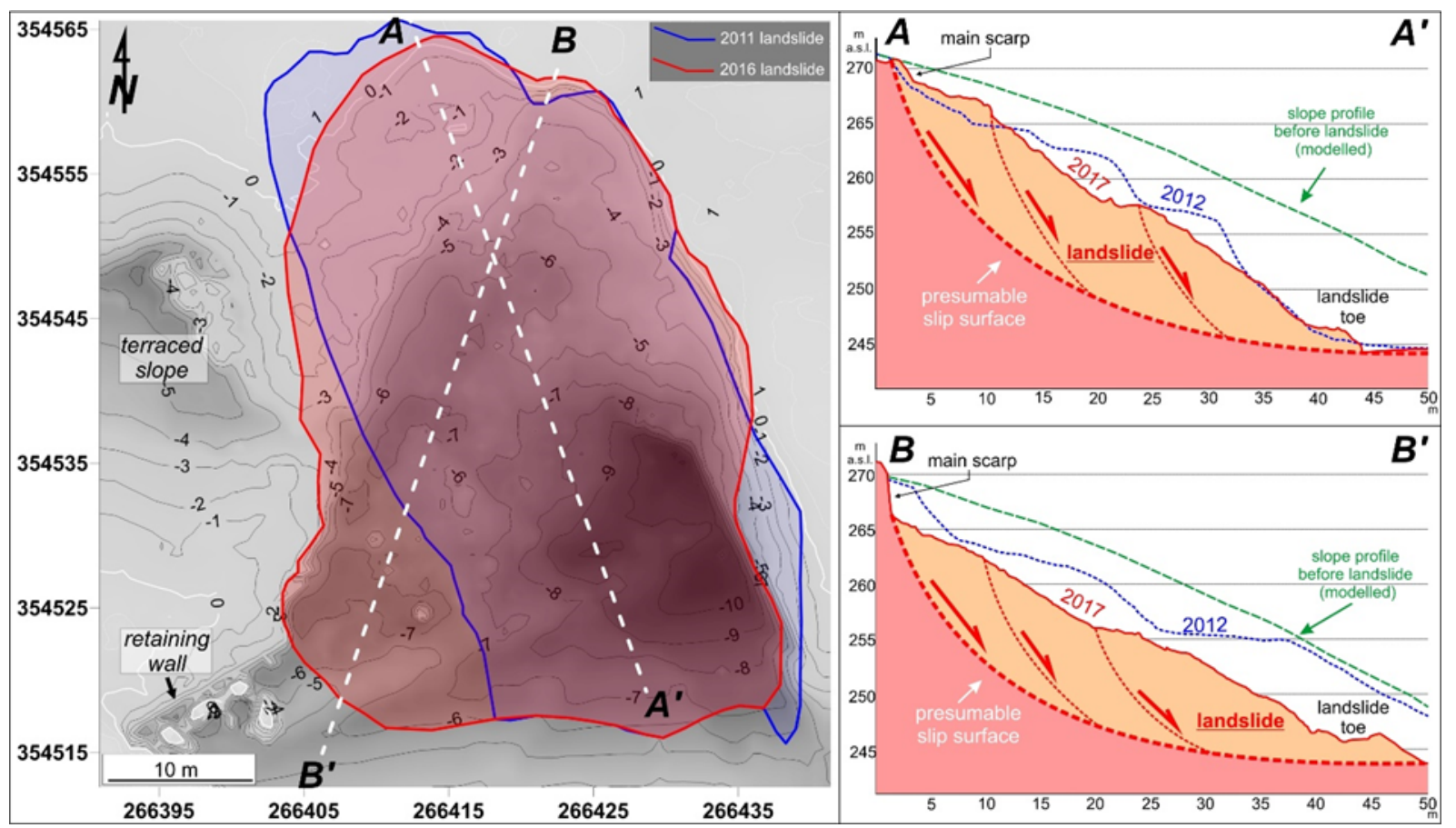

Fig. 7 Comparison of the extents of the 2011 and 2016 landslides. Cross-sections A-A' and B-B' through the landslides obtained from the reconstructed slope surface (green line), LiDAR-derived DTM (blue line) and UAV-derived DTM (red line). Profiles show changes in the longitudinal profile of the slope affected by mass movements and anthropogenic changes described in the paper.

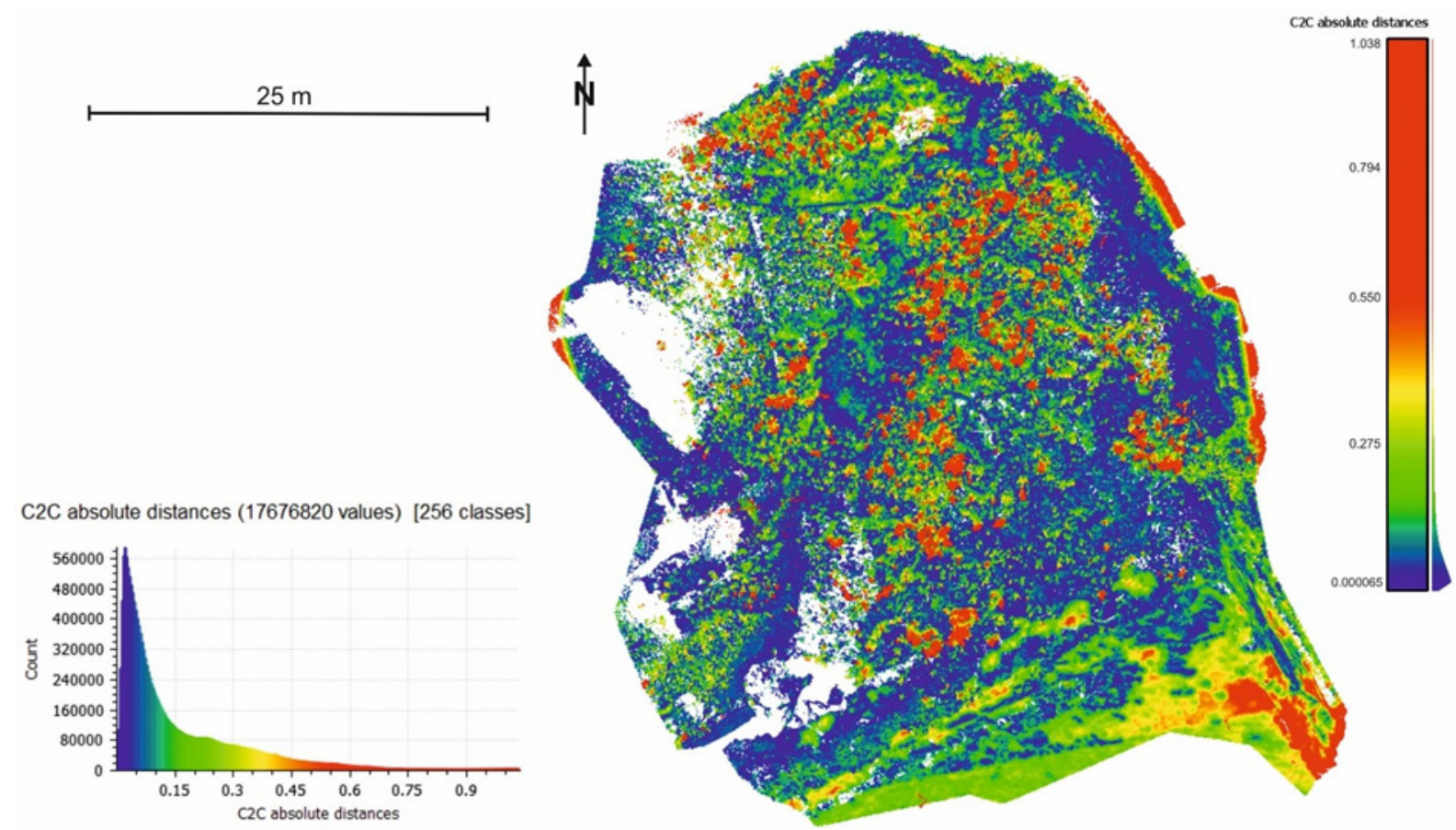

Fig. 8 Internal Quality Control of UAV's DSM (19-09-2017) to TLS DSM (15-12-2017) as reference cloud to cloud absolute distance.

and lower part of the landslide. Zones of positive values, characteristic of the toe zones of the landslide, are visible only on the resultant differential map (Fig. 6D). Areas with positive values visible on differential maps to the west and north of the landslide are correlated with the slope fragments loaded by the guesthouse owners by material from the landslide colluvium (Figs. 6B, C, D). The effect of a small-scale slope loading to the north of the 2011 landslide is particularly evident on the A-A' cross-section based 
on LiDAR data from 2012 (Fig. 7). The slope surface at that time was located at a higher elevation than the slope line in 2017, despite further development of mass wasting. The anthropogenic slope loading below the main scarp of the landslide between 2012 and 2017 also resulted in the mass gain and changing of the slope profile (Fig. 7).

Differential map 3 is the most accurate presentation of the landslide processes between 2016 and the end of 2017 (Fig. 6D). Zones of maximal values of vertical depressions directly correspond to the location and shape of scarps and individual rocky blocks within the landslide. This is evidenced by changes on the longitudinal profile of the slope reflected on the morphological cross-sections (Fig. 7). The zone of mass increment to the south-west of the landslide corresponds to the localization of the retaining wall in 2014, whereas the zone of negative values is related to the place where the slope was terraced.

The validity of the applied UAV methods was confirmed by control of data consistency, which did not indicate significant differences between UAV and TLS models. The results of this analysis are presented in Figure 8. The calculated absolute normal distances between the analyzed point clouds result from changes of terrain cover. The analysis did not indicate vertical changes in the landslide area in relation to UAV DEM. Visible differences reaching maximally $0.45 \mathrm{~m}$ represent class 3 low vegetation according to ASPRS LAS 1.4. (ASPRS, 2012), which were registered using high-resolution TLS, but have not been reconstructed based on UAV photogrammetric images. The future research will focus on horizontal changes monitoring with application of Very High-Resolution Satellite (VHRS) remote sensing imagery and UAV data.

\section{SUMMARY}

The Czerwony Wąwóz landslide was formed as a result of undercutting and strong watering of the slope in 2011 and later in 2016. Slope terracing was aimed at enlarging the surface of the area adjacent to the guesthouse and construction of pedestrian paths in its neighbourhood. The paths and stone reinforcements additionally loaded the valley slope. Slope loading induced reactivation of mass wasting in 2016 and enlargement of the surface area of the 2011 landslide (cf. Figs. 4, 7). The $6 \mathrm{~m}$ high concrete retaining wall with drainage, aimed at stabilizing the slope, turned out to be insufficient reinforcement and was destroyed during landslide reactivation in 2016. Beside anthropogenic factors (slope terracing and loading) and intense rainfall, the indirect cause for increased mass wasting in this area was large lithological variability of Permian deposits (sandstones, siltstones and claystones) and a strikeslip faults occurring in the landslide basement (Kowalski, 2017a; Fig. 4).

Small dimensions and lack of vegetation within the landslide make it a perfect study area to perform monitoring of mass wasting processes. The performed analyses confirmed current manifestations of landslide activity observed during fieldwork and showed the usefulness of short range airborne photogrammetric images.

The obtained differential maps allowed for assessing relative vertical displacement values on the slope and reconstructing the evolution of its transformation by mass movements. The initial slope surface model enabled to determine areas, which might be particularly prone to reactivation and occurrence of new landslide processes in the future. These areas include parts of the slope that were terraced and loaded, and are located to the north and west of the landslide.

Analysis of landslide activity based on measurement data from different periods and sensors (LiDAR, UAV, TLS) creates problems according to data integration. LiDAR measurements provide information with a high degree of generalization (low density of points per $\mathrm{m}^{2}$ ), which represent the surface area after filtering out land cover elements. Similarly, using the UAV imaging and computer vision as well as photogrammetry constrains for the landslide modelling, the reconstructed surface faithfully represents the digital terrain model. On the contrary, a dense data set (point cloud) from TLS requires filtration to remove terrain cover elements. It is also important to stress that the resulting model is not free of occlusion (cf. Fig. 8 - left-bottom part of model). High-resolution TLS point cloud registered elements of low vegetation, which made it impossible to identify changes in the morphology of the landslide surface. Further work in the TLS data processing will be focused on the problem of data filtration in order to obtain a faithful representation of the surface area as batch data for monitoring the landslide.

The calculated amount of mass decline within the landslide obtained from the TLS- and UAVderived data is very low $(\sim 0.1 \%)$. It resulted from differences occurred during DEM's modeling from TLS and UAV data and might be evantuated from: 1) changes of terrain cover between 19-09-2017 (UAV measurements) and 15-12-2017 (TLS measurements) and 2) reactivation of small scale mass movements within investigated landslide. The indirect reason of this discrepancies may resulted from aforementioned differences between TLS and UAV data - both the quality of raw measurement data (significantly higher density of point cloud from TLS) as well as the algorithms used to build DEM models; cf. Figure 8.

According to measurements carried out with UAV and TLS techniques, it is also important to ensure that ground control points are located outside the area of potential landslide activity. Thus, the obtained reference frame stability allows for metric analysis results. Precise reconstruction and further registration of mass wasting near Wlen will be possible thanks to systematic landslide monitoring using UAV and TLS. 


\section{ACKNOWLEDGEMENTS}

This work was financed by the Internal Grant for Young Researchers No. 0420/2285/17 (University of Wrocław), the Polish Statutory Research Grant No. $0402 / 0137 / 16$ and No. 0402/0146/16 (Wrocław University of Science and Technology). LiDAR data have been used for this study on the basis of the academic license No. DIO.DFT.DSI.7211.1619.2015_PL_N issued for the University of Wrocław by the Head Office of Geodesy and Cartography in Poland.

Authors would like to thank K. Maciejak for share a photo from Figure $5 \mathrm{~A}$.

\section{REFERENCES}

Assilzadeh, H., Levy, J.K. and Wang, X.: 2010, Landslide catastrophes and disaster risk reduction: A GIS framework for landslide prevention and management. Remote Sensing, 2, 9, 2259-2273.

DOI:10.3390/rs2092259

Chen, Z., Zhang, B., Han, Y., Zuo, Z. and Zhang, X.: 2014, Modeling accumulated volume of landslides using remote sensing and DTM Data. Remote Sensing, 6, 1514-1537. DOI: $10.3390 /$ rs6021514.

CODGiK: 2017, Geodesic and Cartographic Documentation Center. Available

online: http://www.codgik.gov.pl/, access date 5 November, 2017, (in Polish).

Cook, L.K.: 2017, An evaluation of the effectiveness of low-cost UAVs and structure from motion for geomorphic change detection. Geomorphology, 278, 195-208. DOI: 10.1016/j.geomorph.2016.11.009

Gorczyca-Skała, J.: 1977, Geological structure of the Wlen Graben. Geologia Sudetica, 12, 71-100, (in Polish).

Gotowała, R., Kowalski, A., Sobczyk, A. and Wojewoda, J.: 2015, Structurally-controlled landslide (Toczek Mt., Intrasudetic Shear Zone). In: 16th Czech- Polish Workshop „On Recent Geodynamics of the Sudeten and Adjacent Areas", Srebrna Góra, Poland, November 5-7, Abstracts, 23.

Hampton, M.A. and Griggs, G.B.: 2004, Formation, evolution, and stability of coastal cliffs: status and trends. U.S. Geological Survey Professional Paper 1693.

Hsiao, C.Y., Hsieh, P.S. and Chi,S.Y.: 2013, Assessing volume earthwork by using unconventional photogrammetry. In: Landslide Science and Practice, Springer, Berlin, Heidelberg, 49-56.

ISOK: 2017, Report of delivery, ISOK - IT System of Country Protection against extraordinary threats, Part No. 3, Stage No. 03, 2011-09-12, (in Polish).

Jozkow, G. and Toth, C.: 2014, Georeferencing experiments with UAS imagery. ISPRS Annals of the Photogrammetry, Remote Sensing and Spatial Information Sciences, 2, 1, 25-29.

Kondracki, J.: 2002, Regional geography of Poland. PWN, Warszawa.

Kowalski, A. and Maciejak, K.: 2016, Application of geomorphometric methods in mining-related ground deformation analysis - an example of the "Nowy Kościół" Copper Mine ("The Old Copper Basin", North-Sudetic Synclinorium). Biuletyn PIG, 466, 137-146, (in Polish).
Kowalski, A.: 2016, Human- or structurally-induced landslide? An example from Czerwony Wąwóz (Wleń Graben, Sudetes). 17th Czech-Polish Workshop "On Recent Geodynamics of the Sudeten and the Adjacent Areas, Ramzová, Czech Republic, October 20-22, 2016. Abstracts, 52-53.

Kowalski, A.: 2017a, Distribution and origin of landslide forms in the Bóbr river valley near Wleń (Western Sudetes). Przegląd Geologiczny, 65, 10/1, 629-641, (in Polish).

Kowalski, A.: 2017b, Fault geometry and evidence of depocentre migration within a transtensional intrabasinal high - a case study from the Lączna Anticline (Intrasudetic Synclinorium, SW Poland). Geological Quarterly, 61, 4, 779-794. DOI: 10.7306/gq.1372

Kowalski, A. and Wojewoda, J.: 2017, Newly recognised landslide forms in the Kaczawa river valley (Kaczawskie Foothills, Western Sudetes). Landform Analysis, 34, 15-27, (in Polish).

DOI: $10.12657 /$ landfana-034-002

Lindner, G., Schraml, K., Mansberger, R. and Hübl, J.: 2016, UAV monitoring and documentation of a large landslide. Applied Geomatics, 8, 1, 1-11.

DOI: $10.1007 / \mathrm{s} 12518-015-0165-0$

Ling, S. and Evans, S.G.: 2014, GIS-based analysis of 1933 Diexi Landslides and dam breach on the Min River, Sichuan, China. EGU General Assembly 2014, held 27 April - 2 May, 2014 in Vienna, Austria.

Lucieer, A., Jong, S.M.D. and Turner, D.: 2014, Mapping landslide displacements using Structure from Motion (SfM) and image correlation of multi-temporal UAV photography. Progress in Physical Geography, 38, 1, 97-116.

Maciejak, K., Kowalski, A. and Maciejak, M.: 2017, Goldmines of Wielisławka Hill (Kaczawa Upland). Hereditas Minariorum, 4, 45-63, (in Polish).

Migoń, P. and Kasprzak, M.: 2011, Morphological evidence of mass movements on the escarpments in the Stołowe Mountains in the light of high resolution Digital Elevation Model. Przyroda Sudetów, 14, 115-124, (in Polish).

Migoń, P., Jancewicz, K., Różycka, M., Duszyński, F. and Kasprzak, M.: 2016, Large-scale slope remodelling by landslides - Geomorphic diversity and geological controls, Kamienne Mts., Central Europe. Geomorphology, 289, 134-151. DOI: $10.1016 /$ j.geomorph.2016.09.037

Milewicz, J. and Frąckiewicz, W.: 1983, Detailed Geological Map of the Sudetes 1 : 25 000. Sheet: Wleń. Wyd. Geol., Warszawa.

Niethammer, U., James, M.R., Rothmund, S., Travelletti, J. and Joswig, M.: 2012, UAV-based remote sensing of the Super-Sauze landslide: Evaluation and results. Engineering Geology, 128, 2-11.

DOI: $10.1016 /$ j.enggeo.2011.03.012

Niethammer, U., Rothmund, S., James, M.R., Travelletti, J. and Joswig, M.: 2010, UAV-based remote sensing of landslides. International Archives of Photogrammetry, Remote Sensing and Spatial Information Sciences, 38 (Part 5), 496-501.

Oberc, J.: 1957, The Bardzkie Mountains region (Sudetes). Wyd. Geol.,Warszawa, (in Polish).

Qiu, J., Wang, X., He, S., Liu, H., Lai, J. and Wang, L.: 2017, The catastrophic landslide in Maoxian County, Sichuan, SW China, on June 24, 2017. Natural Hazards, 89, 3, 1485-1493. DOI: $10.1007 / \mathrm{s} 11069-017-3026-9$ 
Roncella, R. and Forlani, G.: 2015, A fixed terrestrial photogrammetric system for landslide monitoring. In: Modern Technologies for Landslide Monitoring and Prediction, 43-67. Springer, Berlin, Heidelberg.

Rossi, G., Nocentini, M., Lombardi, L., Vannocci, P., Tanteri, L., Dotta, G., Bicocchi, G., Scaduto, G., Salvatici, T., Tofani, V., Moretti, S. and Casagli, N.: 2016, Integration of multicopter drone measurements and ground-based data for landslide monitoring. Landslides and engineered slopes. Experience, Theory and Practice, Associazione Geotecnica Italiana, Rome, $1745-1750$.

Rossi, G., Tanteri, L., Salvatici, T. and Casagli, N.: 2017, The use of multi-copter drones for landslide investigations. $3^{\text {rd }}$ North American Symposium on Landslides, Roanoke, VA, June 4-8, 2017, 978-984.

Różycka, M., Michniewicz, A., Migoń, P. and Kasprzak, M.: 2015, Identification and morphometric properties of landslides in the Bystrzyckie Mountains (Sudetes, SW Poland) based on data derived from airborne LiDAR. Geomorphometry for Geosciences, 1, 247250.

Samieinejad, M. M., Hosseini, N. and Ahangari K.: 2017, A field investigation of application of digital terrestrial photogrammetry to characterize geometric properties of discontinuities in open-pit slopes. Journal of Mining and Environment, 8, 3, 455-465. DOI: $10.22044 /$ jme. 2017.930

Sikora, R., Kowalski, A. and Piotrowski, A., 2016a. Implications of landslides development and basement geology diversity along the Bóbr River Valley in the Izerskie and Kaczawskie Highlands area (Western Sudetes). $3^{\text {rd }}$ Polish Geological Congress, 1418.09.2016, Wrocław, 348-350, (in Polish).

Sikora, R., Wojciechowski, T. and Piotrowski, A.: 2016b, Geological and morphological characteristic of landslides close to the Nysa Kłodzka Valley gorge in the Bardzkie Mountains (Sudetes). $3^{\text {rd }}$ Polish Geological Congress, 14-18.09.2016, Wrocław, 351352, (in Polish).

Smith, C.A. and Mikko, H.: 2017, Coastal landslides associated with confined aquifers and land uplift in Sweden. SGU-rapport 2017:06.

Stumpf, A., Malet, J.-P., Allemand, P., Pierrot-Deseilligny, M. and Skupinski, G.: 2015, Ground-based multi-view photogrammetry for the monitoring of landslide deformation and erosion. Geomorphology, 231, 130 145. DOI: $10.1016 /$ j.geomorph.2014.10.039

Synowiec, G.: 2003, Landslides in the Kamienne Mts, Sudetes (SW Poland). Przegląd Geologiczny, 51, No. 1, 59-65, (in Polish).

Turner, D., Lucieer, A. and de Jong, S.M.: 2015, Time series analysis of landslide dynamics uan unmanned aerial vehicle (UAV). Remote Sensing, 7, 2, 17361757. DOI: $10.3390 /$ rs 70201736

Tyszkowski, S.: 2014, Distribution and origin of contemporary lowland landslides in the area of the direct river impact, on the example of section of Lower Vistula Valley between Morsk and Wiąg. Landform Analysis, 25, 159-167, (in Polish). DOI: $10.12657 /$ landfans.025.014
Urbański, K., Różański, P., Ćmielewski, B., Kontny, B., Ostrowski, S., Lasocki, M., Farbisz, J. and Mżyk, S.: 2015, Complex geological and geophysical survey in the Janowiec Landslide. Ogólnopolska Konferencja Osuwisko, Wieliczka, 19-22 maja 2015, Polish Geological Institute-National Research Institute, Warszaw, 75-76, (in Polish).

Violante, C. (Ed.): 2009. Geohazard in Rocky Coastal Areas. The Geological Society of London. DOI: $10.1144 /$ SP322

Wajs, J.: 2015, Research on surveying technology applied for DTM modelling and volume computation in open pit mines. Mining Science, 22, 75-83. DOI: $10.5277 / \mathrm{sc} 152207$

Wajs, J.: 2016, Experiment with remotely piloted aircraft systems imagery for DTM modelling. Archiwum Fotogrametrii, Kartografii i Teledetekcji, 28, 125-136, (in Polish). DOI: 10.14681/afkit.2016.010

Wieczorek, G.F., Larsen, M.C., Eaton, L.S., Morgan, B.A. and Blair, J.L.: 2001, Debris-flow and flooding hazards caused by the December 1999 storm in coastal Venezuela (USGS Open-File Report 01-144). US Geological Survey, Reston, VA.

Wójcik, A. and Wojciechowski, T.: 2016, Landslides as one of the most important elements of geological hazards in Poland. Przegląd Geologiczny, 64, 9, 701-709, (in Polish).

Zhang, D. and Wang, G.: 2007, Study of the 1920 Haiyuan earthquake-induced landslides in loess (China). Engineering Geology, 94, 1-2, 76-88. DOI: 1016/j.enggeo.2007.07.007

Zieliński, T.: 2001, Erosional effects of catastrophic floods in the Nysa Kłodzka drainage basin during the 1997 and 1998 events (SW Poland). Przegląd Geologiczny, 49, 11, 1096-1100, (in Polish). 